\title{
The Sarbanes-Oxley Act and Accounting Quality: A Comprehensive Examination
}

\author{
Martijn Verleun \\ Amsterdam Business School, University of Amsterdam, Netherlands \\ E-mail: martijnverleun@hotmail.com
}

Georgios Georgakopoulos

Corresponding Author, Amsterdam Business School, University of Amsterdam, Netherlands

E-mail: g.georgakopoulos@uva.nl

Ioannis Sotiropoulos

Department of Finance and Auditing, TEI of Epirus, Greece

E-mail: sotiropoulosioan@yahoo.gr

Konstantinos Z. Vasileiou

Department of Business Planning \& Information Systems, TEI of Patras, Greece

E-mail: vasileiou@teipat.gr

Received: January 19, 2011

Accepted: February 10, 2011

doi:10.5539/ijef.v3n5p49

\begin{abstract}
This paper investigates the impact of the Sarbanes-Oxley (SOX) Act on the quality of financial statement information. Where other papers have only investigated the short-term effects of SOX, this paper takes a longer post-SOX period. A distinction is also made between technology and non-technology based firms. Earnings management, conservatism and value relevance measures were used in order to examine the impact of SOX on accounting quality. A significant increase was found on both the earnings management and value relevance measures, which was persistent over a four-year post-SOX period. On the contrary, a slight increase in conservatism was observed, however these results are not significant. Moreover, the technology based firms score worse on the earnings management measure, thus, the separate investigation between technology and non-technology based firms has revealed interesting information which would otherwise have stayed undetected.
\end{abstract}

Keywords: Sarbanes-Oxley Act, Accounting quality, Earnings management, Conservatism, Value relevance, Technology and non-technology based firms

\section{Introduction}

Currently the economic world is suffering the consequences from the credit crisis which hit the financial system in 2008. Most commentators contribute the occurrence of this crisis, amongst others, to the application of overaggressive credit policies and poor financial risk management (e.g. Diamond and Rajan, 2009; Lim, 2008). Despite the fact that those mistakes made at the financial institutions that instigated the current crisis, no thorough regulatory actions have been taken by the national and international standard setters until this point in time. The situation was completely different at the beginning of this century when the world was shocked by the high-profile accounting scandals. The U.S. Government reacted unprecedentedly fast with a legislation aimed to improve accounting and auditing for U.S. listed firms, better known as the Sarbanes-Oxley Act (hereafter referred to as SOX or the Act). Countries in Europe reacted in the same way with similar legislations aimed at improving corporate governance and financial reporting.

Since then a great deal of critique has been expressed on these legislations and in particular on the Act (e.g. Ball, 2009; Engel et al., 2007; Ribstein, 2005). Those critiques focus primarily on the high costs associated with compliance to the provisions of SOX. However, for a decent assessment of a regulatory intervention (like the SOX Act) the disadvantages must be traded off against the advantages. Measuring the direct costs associated with compliance is nevertheless much easier than quantifying the benefits. Therefore more attention is often paid to 
mentioning the negative consequences of SOX than to measure some of the benefits.

The aim of our work here is to examine the impact the Act had on the quality of financial statement reporting. In order to achieve this we investigate a longer post-SOX period than what the previous literature has done on specific metrics involving conservatism and value relevance measures. For a better tuning of our examination we also make a distinction between technology and non-technology firms.

In this light our paper proceeds as follows: In the next section we briefly discuss the Act, related measures of accounting quality in financial statement analysis, prior studies conducted on SOX and we introduce our rationale on the differences between technology and non-technology firms. We then present our hypotheses, methodology, methods, and our research findings. Our work ends with our conclusions and limitations that we see in our examination.

\section{Related Literature}

\subsection{The Sarbanes-Oxley Act}

On July 30, 2002 Congress passed the Sarbanes-Oxley Act, mainly as a reaction to the high-profile corporate accounting scandals of, among others, Enron, Ahold and WorldCom. Its primary purpose was to fix and enhance the quality of governance and financial statement information of U.S. listed firms (Coates, 2007). This implicit aim was derived from the fact that unqualified financial statements are the primary output of audits and that increased liability risk should ideally lead to more carefulness from executives (Black et al., 2006; Kinney et al., 2004).

Sections 302 and 404 have received the most attention of all the SOX provisions. Section 302 deals with corporate responsibility for financial reports. In practice this means that both the CEO and CFO of a public firm must take responsibility for the content of the financial report and sign for this (U.S. House of Representatives, 2002).

Section 404 deals with the assessment of internal controls by management. Management is obliged to take responsibility for the establishment and maintenance of internal controls and it must assess the effectives of the internal control structure and the procedures for financial reporting. Section 404 also obliges the auditor to assess whether the assertions made by management are fair or not (U.S. House of Representatives, 2002).

\subsection{Measures of Accounting Quality}

Despite the fact that accounting quality is a concept to which many research papers refer, there is no uniform definition of what accounting quality exactly comprises. Barth et al. (2008) define accounting quality as the ability of accounting measures to reflect the economic position and performance of a firm. With this definition the focus is primarily on the relevance of the information provided. Other definitions of accounting quality focus more on the reliability of financial information; according to this definition higher quality accounting information should benefit investors and other stakeholders by protecting them against opportunistic behavior of management (Penman and Zhang, 2002; Watts, 2003).

This dichotomy between the different accounting quality definitions reveals one of the inherent problems which exist with the reporting of financial information, namely the trade-off between relevance and reliability. This trade-off is also present when it comes to the measurement of accounting quality since some measures focus more on relevance whether others focus more on reliability. While these concepts do sound contradictory this does not automatically mean that an increase in relevance cannot coincide with an increase in reliability. The definition provided above states that accounting quality applies to both the economic position and performance of a firm. Thus accounting quality affects both the balance sheet and the income statement. So it could very well be possible that an increase in the relevance of balance sheet information comes together with an increase in the reliability of income statement information. Therefore an increase in both relevance and reliability is possible thus providing a basis for including multiple measures in this paper.

Since accounting quality is not something which can be observed directly out of the financials, proxies will have to be developed. Previous research has identified several different metrics of accounting quality with the most applied measures being earnings management, conservatism and value relevance (e.g. Barth et al., 2008; Lang et al., 2003).

Value relevance is the metric most in line with the definition of accounting quality provided by Barth et al. (2008). There are several interpretations of what value relevance exactly comprises, however all interpretations are based on an association between accounting information and stock market values (Francis and Schipper, 1999). Francis and Schipper (1999) define value relevance as the ability of financial statement information to capture or summarize information that influences share prices. One serious problem of measuring value relevance is that this metric relies on market information. Thus if the market is highly inefficient a value relevance assessment could result in the conclusion that accounting quality is low while this is not the case. Therefore an implicit assumption for this 
measure to be valuable is that markets are to a certain extent efficient. One way to deal with the shortcomings of a specific quality metric is to use multiple measures for accounting quality.

Probably the most frequently applied metric on accounting quality is measuring the degree of earnings management present in the financial statements. Earnings management is a negative form of accounting quality and can be summarized as the ability of management to use judgment in financial reporting to either mislead some stakeholders or to influence contractual outcomes at their own benefits (Healy and Wahlen, 1999). Because managers do not disclose their personal intentions for a certain accounting choice in the financial statements, earnings management cannot be observed directly out of these financial statements either. Therefore proxies have to be developed.

A third metric on accounting quality which is also frequently applied deals with the timeliness of earnings and especially the asymmetric timeliness of earnings. Asymmetric timeliness (also called conditional conservatism) can be described as a tendency for managers and auditors to require a higher degree of certainty for recognizing good news than bad news in the financial statements (Basu, 1997). Thus conservatism is in fact the practical implementation of the prudence principle described in U.S. GAAP. It is important to distinguish between normal conservatism and conditional conservatism. Whereas conservatism can be explained as the tendency of managers being more prudent in reporting certain events in general, conditional conservatism measures the incremental prudency of managers to report 'good news'. The terms conservatism and conditional conservatism are used interchangeably in this research, only when necessary a separate explanation is given. The reason conservatism is interpreted as providing higher quality earnings is because it benefits the firms' financial statements users (Watts, 2003). Watts (2003) provides several explanations for why users might benefit from conservatism. First of all conservatism can be helpful in addressing the moral hazard problem caused by the information asymmetry faced by interested parties to the firm. Besides it can decrease litigation costs, delay tax expenses and it can benefit standard setters by decreasing their regulatory costs.

The outline regarding the different measures for accounting quality reveals that those measures capture different aspects of accounting quality. While the value relevance measure is of course more concerned with the relevance of financial statement information, the conservatism measure is more concerned with the reliability of this information. The management of earnings can have an impact on both the relevance and reliability of financial statement information. Despite the fact that these measures focus on different aspects of accounting quality they are all included in our analysis since relevance and reliability are both aspects of accounting quality and they are not mutually exclusive, as outlined above.

\subsection{Prior research regarding the impact of SOX Act}

Prior research has already investigated the impact of the SOX Act on accounting quality. These papers can be divided in two general categories. The first category has examined whether investors expect the implementation of the SOX Act to be beneficial in terms of providing better accounting information (e.g. Goncharov et al., 2006; Li et al., 2008; Zhang, 2007). The second category of papers has examined whether the SOX Act has had a real perceived impact on financial statement information (e.g. Cohen et al., 2005; Lobo and Zhou, 2006). Regarding the first category the evidence is mixed. While some papers find an abnormal positive market return associated with the enactment of SOX and comparable governance codes (Goncharov et al., 2006; Li et al., 2008), another paper finds contradictory evidence (Zhang, 2007).

Lobo and Zhou (2006) examined whether the enactment of SOX had an influence on the degree of conservatism in financial reporting. They compare conservatism in the pre- and post-SOX period by using both the degree of discretionary accruals and the Basu (1997) method to measure conservatism, although, most other studies use discretionary accruals as a measure for earnings management. They interpret lower discretionary accruals as evidence for more conservatism; however they lack a solid justification for this assumption. Despite the doubts regarding this second proxy, both proxies show a significant increase in conservatism shortly after SOX became effective. One important remark which should be made is that this work has a fairly short post-SOX period which ends in 2003. So this paper provides initial evidence for an increase in conservatism and thus an increase in accounting quality after SOX.

Cohen et al. (2005) also examined accounting information pre- and post-SOX. Instead of conservatism they examine the effect of SOX on the propensity of firms to manage earnings. They use three measures of discretionary accruals, three ratios which capture some aspect of earnings management and the frequency of special items reported. Based on these measures they calculate an earnings management score for each of the 2,078 companies of their sample over the period 1987-2003, in order to make a distinction between the period in which the major scandals occurred and the period preceding this period. Their findings convincingly show that there has been a rapid increase in earnings management which peaked during the period of the accounting scandals. However, after the passage of 
SOX the degree of earnings management declined abruptly and significantly. This again provides evidence for a positive influence of SOX on accounting quality, though it is only initial evidence (again) due to the short post-SOX sample length.

Other papers have also investigated whether the market expected SOX to have a positive influence on firms and their reporting of financial information. This is done under the assumption that stock markets are efficient, reflecting all the available information in a timely manner (Zhang, 2007; Aggelopoulos et al., 2008). Market efficiency implies that when investors expect SOX to be beneficial and thus value increasing there should be positive abnormal returns related to specific important SOX related events. An example of such an event is for instance the day on which Congress passed the SOX Act. One of the first papers which have examined the relation between those events and the stock market reaction is by $\mathrm{Li}$ et al. (2008). They calculate the abnormal returns associated with eight different SOX events for a total sample of 850 U.S. firms. Not all event days show a significant positive return but the average positive return over all the event days is $12,5 \%$ ( $\mathrm{Li}$ et al., 2008). These results are consistent with investors anticipating SOX to have a net positive impact.

Not all studies come to the same conclusion. Zhang (2007) conducts a study comparable to the one of Li et al. (2008), using the same and additional events, and he reports contradictory findings. Overall Zhang (2007) finds a negative abnormal return associated with the identified SOX events. Zhang (2007) devotes an appendix to the explanation of why the findings of his study differ from the ones of Li et al. (2008). He attributes this effect primarily to the use of different event windows and the inclusion of additional events. Because none of the approaches leads to really convincing results it could be argued that the evidence with respect to the expectations of investors about the influences of SOX is mixed.

However, research conducted by Goncharov et al. (2006) provides additional indirect evidence for the assertion that stock markets value the enactment of a corporate governance code. Instead of SOX, Goncharov et al. (2006) examine the market reaction to the declared degree of compliance with the German Corporate Governance Code (GCGC) for a sample of large listed firms in Germany. In contrast to SOX, GCGC does not require full compliance to all provision. Firms are free to choose their degree of compliance which makes it possible to investigate whether the stock market values a higher degree of compliance to the governance code. Their findings confirm that the degree of compliance is positively associated with the value relevance of accounting information, thus they provide evidence for the expectation that the enactment of a corporate governance code is valued by investors. In relation to SOX this implies that it would be expected that the stock market will value SOX compliance because of an expected increase in the relevance and reliability of accounting information (Goncharov et al., 2006).

Despite the positive intentions of the Act it has received a great deal of critique. Those critiques mainly focus on the high compliance-costs associated with SOX (e.g. Ball, 2009; Ribstein, 2005). In a response to these critiques Engel et al. (2007) have empirically assessed whether the enactment of SOX has encouraged firms to delist from the stock exchange in an attempt to avoid SOX compliance. This tendency to 'go-private' can come with high social costs (Ribstein, 2005). First of all firms can benefit from being publicly listed because this leads to the potential of raising more funds. Besides, investors benefit from the opportunity to diversify their investment risk. Secondly, with firms going private a lot of information is lost for the market which is caused by lower level of required disclosure transparency. Thirdly, public ownership leads to positive social externalities which may be lost if firms go private.

Engel et al. (2007) show that for the period 1998-2005 the frequency of going-private transactions has increased after the passage of SOX. In the 34 months preceding SOX 159 firms went private while in the 33 months after SOX a total of 243 firms went private. Although this difference is significant it is questionable whether it has got economic substance because the absolute value of going-private cases represents still a small portion of all U.S. listed firms. However, the findings can be interpreted as evidence for one of the downsides of SOX, namely the high compliance-costs.

\subsection{Differences between Tech and Non-tech Firms}

Existing research has already examined differences in accounting quality between different settings extensively. For example, Ball et al. (2000) investigate whether there is a difference in conservatism between different institutional settings and Leuz et al. (2003) investigate whether the degree of earnings management differs with international differences in investor protection. Minor investigation is undertaken regarding the difference in accounting quality between technology and non-technology based firms.

One of the few studies dealt with this issue (Kwon et al., 2006) showed that high-tech firms have a higher degree of accounting conservatism in their earnings figures than low-tech firms. One possible explanation for this difference is that accounting standards mandate high-tech firms to apply more conservative standards. Besides, the higher volatility of high-tech stocks makes these firms more vulnerable to shareholder litigation. High-tech firms also 
attract more attention from analysts because of their high growth potential, thus they may become incentivized to report more prudently (Kwon et al., 2006). While the reporting requirements for technology based firms are substantially different from non-technology ones, they may also differ on other measures of accounting quality (Aboody and Lev, 1998; Kallapur and Kwan, 2004). Therefore a separate investigation of technology based firms has the potential to reveal interesting information.

The distinction between tech and non-tech firms may also be valuable because the period of investigation is heavily influenced by the dot-com bubble in the late 1990's. This pattern was mostly experienced by firms in the technology sector. Especially the value relevance measure is influenced by the dot-com bubble since the main characteristic of the phenomenon was the extreme increase in share prices; one of the main inputs in the value relevance test (Goldfarb et al., 2006).

\section{Hypotheses Development and Methods}

\subsection{Aim and Research Hypotheses of the study}

Prior research has already shown that conservatism has increased after SOX and that the degree of earnings management has declined (Cohen et al., 2005; Lobo and Zhou, 2006). However, both studies only provide very early evidence on these consequences because of their short post-SOX periods (of only one year-data). Thus, it is interesting to investigate whether the influence of SOX on accounting quality has been sustainable or whether it was just a short-term effect. Besides, no prior research has paid attention to the influence of SOX on a third measure of accounting quality, namely the value relevance of accounting information.

Prior research has already shown that technology firms are, ceteris paribus, more conservative than non-tech firms (Kwon et al., 2006). Yet less is known about the difference in earnings management and value relevance between these types of firms. The fact that both types of firms are confronted with the heavy legislation of the Act also creates the possibility to investigate whether these types of firms react differently on those requirements.

All these considerations together lead to the following main research questions:

"Has the implementation of the Sarbanes-Oxley Act improved accounting quality? To what extent has any potential increase been sustainable? Where have these effects been different for technology firms compared to non-technology firms?"

One of the primary intentions of the regulators to implement the SOX requirements was to enhance the quality of financial statements for public listed firms. Therefore, higher accounting quality is expected after the enactment of SOX. This expectation is further strengthened by the findings reported in the literature section, especially those of Lobo and Zhou (2006) and Cohen et al. (2005). Thus, our first research hypothesis is:

H1: Accounting quality has improved in the post-SOX period compared to the pre-SOX period.

To operationalize this first hypothesis it is necessary to have some metrics on accounting quality. In this paper our focus will be on three measures of accounting quality that are the most frequently applied in previous studies concerning quality of accounting information; namely earnings management, conservatism and value relevance (e.g. Barth et al., 2008; Lang et al., 2003). This rationale results in the following sub-hypotheses:

H1a: The degree of earnings management has declined in the post-SOX period compared to the pre-SOX period.

$H 1 b$ : Earnings are more conservative in the post-SOX period compared to the pre-SOX period.

H1c: Earnings and book values are more value relevant in the post-SOX period compared to the pre-SOX period.

With respect to the persistency of this hypothesized improvement in accounting quality no supporting evidence is available. However, because the requirements of the Act have not changed substantially over time and because firms may have become more experienced with the application of SOX, it is also expected that the effects of SOX are sustainable after the first year. It could even be that the increase in accounting quality has grown after the first year because of the experience effects. This leads to our second hypothesis:

\section{H 2: The improvement in accounting quality is persistent over the post-SOX period.}

Whether SOX has a differential influence on high-technology firms compared to low-technology firms is uncertain. There is no theory available to support any claim regarding a differential influence on these types of firms. Therefore the third hypothesis is formulated as a null hypothesis. In conjunction with this third hypothesis the cross-sectional difference in accounting quality will also be examined.

Evidence found by Kwon et al. (2006) reveals that technology based firms are more conservative compared to non-technology firms, thus providing evidence for higher accounting quality. However, with respect to the other quality measures no prior evidence is available; therefore the hypothesis regarding this question is also formulated 
as a null hypothesis.

The above lead to our last two hypotheses:

H3: There is no difference in the influence of SOX on accounting quality between technology firms and non-technology firms.

H4: There is no cross-sectional difference in accounting quality between technology based firms and non-technology based firms.

\section{Methodology and Data Collection}

\subsection{Methodology}

In order to test our research hypotheses we use different models for each of the accounting quality metrics employed in our study.

\subsubsection{Earnings Management}

There are two general ways to measuring earnings management; with discretionary accrual models or models based on the distribution of earnings. We made a choice on a discretionary accrual model since metrics based on earning distributions are surrounded by ambiguity (see McNihols, 2000). Discretionary accrual models are also not free from errors but to a lesser degree. Besides most prior research regarding earnings management have used discretionary accrual models to measure earnings management. Therefore comparability increases with the application of a discretionary accrual model.

Multiple discretionary accrual models are used in the existing literature. The modified Jones-model is by far the most applied model in those studies. Dechow et al. (1995) have demonstrated that this model exhibits the most power in detecting earnings management when applied to four different samples. Although Kotari et al. (2005) have developed an even further modified version of the Jones-model the original modified version will be used for this research since the Kothari et al. (2005) model is not applied yet in any well-known papers on earnings management and it could potentially make the interpretation of our results problematic.

The primary purpose of the modified Jones-model is to measure the discretionary accruals for a firm $i$ in year $t$. This measure is then a proxy for the degree of earnings management because managers have been able to exercise discretion over this amount. For the measurement of discretionary accrual the total accruals have to be calculated first. This is done according to the following model (Dechow et al, 1995):

$$
T A_{i t}=\left(\Delta C A_{i t}-\Delta C L_{i t}-\Delta \text { Cash }_{i t}+\Delta S T D_{i t}-D E P_{i t}\right) /\left(A_{i t-1}\right)
$$

Where, for firm $i$ and year $t$ : TA $=$ total accruals; $\Delta \mathrm{CA}=$ change in current assets; $\Delta \mathrm{CL}=$ change in current liabilities; $\Delta$ Cash $=$ change in cash and cash equivalents; $\Delta \mathrm{STD}=$ change in debt included in current liabilitie; $\mathrm{DEP}=$ depreciation and amortization expense; $\mathrm{A}=$ total assets

After the total accruals are calculated this amount should be decomposed in a discretionary and a non-discretionary part:

$$
T A_{i t}=N D A_{i t}+D A_{i t}
$$

Where, for firm $i$ and year $t$ : NDA $=$ non-discretionary accruals; DA $=$ discretionary accruals

Here is where the modified version of the Jones-model actually comes into the calculation. The special feature of this modified version is namely the way in which the non-discretionary accruals are calculated:

$$
N D A_{i t}=\alpha_{0}+\alpha_{1}\left(1 / A_{i t-1}\right)+\alpha_{2}\left(\Delta R E V_{i t}-\Delta R E C_{i t}\right)+\alpha_{3}\left(P P E_{i t}\right)
$$

Where, for firm $i$ and year $t: \triangle \mathrm{REV}=$ change in revenues scaled by lagged total assets; $\triangle \mathrm{REC}=$ change in net receivables scaled by lagged total assets; $\mathrm{PPE}=$ gross property, plant and equipment scaled by lagged total assets.

If (3) is fit into (2) the following formula is obtained:

$$
T A_{i t}=\alpha_{0}+\alpha_{I}\left(1 / A_{i t-1}\right)+\alpha_{2}\left(\Delta R E V_{i t}-\Delta R E C_{i t}\right)+\alpha_{3}\left(P P E_{i t}\right)+D A_{i t}
$$

This is equal to the following regression equation:

$$
T A_{i t}=\alpha_{0}+\alpha_{1}\left(1 / A_{i t-1}\right)+\alpha_{2}\left(\Delta R E V_{i t}-\Delta R E C_{i t}\right)+\alpha_{3}\left(P P E_{i t}\right)+E_{i t}
$$

Where, for firm $i$ and year $t: \mathrm{E}=$ unstandardized residual

Thus, this unstandarized residual serves as the proxy for the amount of discretionary accruals. The mean of the unstandarized residuals is of course zero. However, for the purpose of this research the direction of earnings management is not important; rather the degree of earnings management is the variable of interest. Therefore the 
absolute value of all the residuals should be taken as the proxy for earnings management. After this is done, the degree of earnings management can be obtained by calculating the mean of the absolute residuals. By comparing these amounts before and after SOX it can be examined whether there has been a change in the degree of earnings management.

\subsubsection{Conservatism}

The Basu (1997) model is the leading model when it comes to the measurement of conservatism. This model measures the asymmetric timeliness of earnings as a proxy for conservatism. Research by Ryan (2006) has revealed that measuring asymmetric timeliness is still the best way for identifying conditional conservatism therefore this model will also be applied for the purpose of this research.

Basu (1997) applies a reverse regression, where annual earnings are regressed on current annual returns, because this leads to better-specified test statistics (Beaver et al. 1980). This results in the following model:

$$
X_{i t} / P_{i t-l}=\alpha_{0}+\alpha_{1} D R_{i t}+{ }_{\beta 0} R_{i t}+{ }_{\beta 1} R_{i t} * D R_{i t}+v_{i t}
$$

Where, for firm $i$ and year $t$; $\mathrm{X}=$ annual earnings per share; $\mathrm{P}=$ price per share; $\mathrm{R}=$ annual stock return; $\mathrm{DR}=1$ if $\mathrm{R}$ $<0$, and 0 otherwise; $v=$ error term.

DR represents the dummy variable which is 1 in the case of a negative return for the year. Therefore $\beta 1$ measures the difference in sensitivity of earnings to negative returns additionally to positive returns. However, with this model it is not possible to make a comparison between the pre-SOX and post-SOX period. Therefore additional dummies must be added to this model to be able to measure whether there is a difference in conservatism between the two periods. Lobo and Zhou (2006) have adjusted the original Basu (1997) model to take this into account:

$$
X_{i t} / P_{i t-1}=\alpha_{0}+\alpha_{1} D R_{i t}+\beta_{0} R_{i t}+\beta_{1} R_{i t} * D R_{i t}+\gamma_{0} C E R T I_{i t}+\gamma_{1} C E R T I_{i t} * D R_{i t}+\gamma_{2} C E R T I_{i t} * R_{i t}+\gamma_{3} C E R T I_{i t} * R_{i t} * D R_{i t}
$$

Where, for firm $i$ and year $t$ : CERTI $=1$ in the post-SOX period, and 0 otherwise

In this model $\beta_{0}$ measures how quickly good news is incorporated in earnings in the pre-SOX period. The corresponding measure for the post-SOX period is $\beta_{0}+\gamma_{2}$. Therefore, $\gamma_{2}$ measures the difference in the timeliness of good news between the two periods. Because managers are expected to be more prudent in the post-SOX period, the expected coefficient for $\gamma_{2}$ is less than 0 . The coefficient of $\beta_{1}$ measures the degree of conditional conservatism in the pre-SOX period and thus $\beta_{1}+\gamma_{3}$ is the corresponding measure in the post-SOX period. Therefore, the change in the degree of conditional conservatism between the two periods is captured by $\gamma_{3}$. Based on the hypothesis that managers will become more conservative after SOX because of the increased fear for legal liability the expected coefficient for $\gamma_{3}$ is greater than 0 .

\subsubsection{Value Relevance}

All value relevance studies are based on an assessment between market values and book values. With this type of regressions the main variable of interest is the explanatory power of the model (adjusted $\mathrm{R}^{2}$ ); a higher adjusted $\mathrm{R}^{2}$ indicates a higher information content of book values (Francis and Schipper, 1999). However, the coefficients on the independent variables could also reveal interesting information regarding the relationship between the dependent and independent variables.

The Ohlson (1995) model is the most popular model for measuring value relevance. This model is especially applicable when value relevance is examined over multiple periods because it allows for inter-period comparison. This model regresses book values on market values. Subsequently the explanatory power of this regression can be used as a proxy for value relevance. This is done on a per share basis to scale for firm size effects:

$$
P_{i t}=\alpha_{o}+\alpha_{1} B V E_{i t}+\alpha_{2} E A R N_{i t}+v_{i t}
$$

Where, for firm $i$ in year $t$ : $\mathrm{P}=$ price per share; $\mathrm{BVE}=$ book value of equity per share; EARN = earnings per share; $v$ $=$ error term.

In this model the coefficient on $\alpha_{1}$ describes the relation between the book value of equity and the market value of the firm and $\alpha_{2}$ describes the relation between the earnings of a firm and its market value. However the combined value relevance of book values is best summarized by the explanatory power of the model, therefore this is the primary figure of interest. After these figures are obtained for both the pre- and post-SOX period a comparison can be made between these periods. In this way it can be examined whether there has been a shift in value relevance after SOX. An increase in value relevance is expected after SOX because the period preceding SOX is characterized by aggressive accounting and extremely overvalued firms. 


\subsection{Data collection}

\subsubsection{Sample of the study}

Since the purpose of this research is to measure accounting quality before and after the enactment of the Sarbanes-Oxley Act, our sample is divided in a pre- and post-SOX period. The first consideration deals with the cut-off point for the post-SOX period. The SOX Act was enacted July 30, 2002, thus all observations after this date are classified as post-SOX. However, U.S. firms are allowed to have a broken book year which implies that not all financial statements for the year 2002 are subject to the SOX Act. Since the large majority of U.S. firms end their book year later than July 30 , it is not possible to construct entirely even pre- and post-SOX samples sizes. Most of the 2002 observations are post-SOX therefore this year will be included as a post-SOX year. The minor observations which are pre-SOX are added to the pre-SOX sample which results in slightly larger pre-SOX samples. Nevertheless this is not expected to be a problem because of the fairly long sample period which will be discussed next.

In order to examine the second hypothesis, the post-SOX period should be of sufficient length; however it should not be too long because other exogenous effects could bias the results. Thus a period of 8 years, 1998-2005, was chosen, with reasonably equal sample lengths for pre- and post-SOX.

The data is obtained from the Compustat North America database. For the purposes of the third and fourth hypotheses two subsamples, for high and low technology firms, are necessary. The sample of technology firms is constructed from the NASDAQ-100 Index. The sample of non-technology firms is subsequently formed by firms listed in the S\&P 100 Index, adjusted for firms already listed in the NASDAQ-100. Financial firms are excluded from the S\&P sample because of their special financial structure.

Because the different accounting quality measures also require different variables to be available, the samples for testing the different hypotheses deviate little from each other. Table 1 provides an overview of the sample sizes for the different hypotheses.

Only firms for which data are available over the entire sample period for all the variables needed to calculate the quality measure are included in the final samples. Outliers are deleted manually by plotting the variables and screening the figures for unusual occurrences.

\section{Research Results}

\subsection{Earnings Management}

Descriptive results for the modified Jones-model are reported in table 2. As expected, for all the three sample compositions, the amount of mean discretionary accruals has declined after the enactment of SOX. It is interesting to notice that there is a difference in the degree of earnings management between technology and non-technology firms. Pre-SOX the degree of discretionary accruals is almost four times as large for technology firms as for non-technology firms, while this ratio had declined to less than three in the post-SOX period.

In table 3, panel A reports the results for the significance tests on the differences of the amount of mean discretionary accruals between the pre- and post-SOX period. The results for the t-tests, both assuming equal and unequal variances, show that the decrease in discretionary accruals is highly significant with p-values being less than $1 \%$ for all occurrences. These findings provide convincing evidence for a decrease in earnings management after SOX was enacted. It could however be that the pre-SOX observations are so much influenced by the internet-bubble that they result in a bias in the findings. Therefore an additional analysis is conducted with a sample period ranging from 2001 till 2003 to better isolate the SOX effect.

The results of this analysis are reported in panel B of Table 3. As a result of the smaller sample sizes the test statistics are smaller, however they still point in the hypothesized direction and for the majority of occurrences they are significant at conventional levels.

Probably the most interesting finding from this additional analysis is that the decrease in earnings management is the least in both magnitude and significance for technology firms. One possible explanation for this occurrence is that the collapse of the dot-com bubble was an early eye-opener for firms active in the technology business. Therefore their financial statements for the fiscal year 2001 already incorporate an increase in accounting quality which is not yet experienced by non-technology firms because they were less subjected to the effects of the dot-com bubble.

Another important finding from this additional analysis is that the decrease in earnings management appears to be fairly sustainable. This conclusion is based on the fact that the mean discretionary accruals for the post-SOX period do not differ substantially between the 2002-2003 and 2002-2005 sample lengths. A statistical analysis comparing mean discretionary accruals in both periods, reported in table 4, also reveals that there is no statistical significant difference in the degree of discretionary accruals between these periods. Thus the decrease in earnings management 
is not of a transitory nature.

The cross-sectional difference in earnings management is also examined between technology firms and non-technology firms (see table 5). Not surprisingly the results show that the degree of earnings management is far greater for technology firms. All the differences are highly significant which implies that, ceteris paribus, firms in the technology sector have lower accounting quality on the earnings management measure.

Based on the different tests for the earnings management hypothesis it can unambiguously be concluded that the degree of earnings management has declined following SOX. For all the different sample compositions the decrease in earnings management is highly significant and this decrease turns out to be persistent in later years after SOX. Furthermore firms in the technology sector manage earnings to a higher degree than firms not active in this industry.

\subsection{Conservatism}

Panel A of table 6 shows that the signs of the important coefficients $\gamma_{2}$ and $\gamma_{3}$ are in the predicted directions. Unfortunately for the period 1998-2005 most coefficients are not significant at conventional levels. Only the increase in conditional conservatism in the post-SOX period for the sample based on non-technology firms is significant at the $1 \%$ level. Thus non-technology firms have become more asymmetrical conservative after SOX has been enacted. However this assertion does not hold for the sample of technology firms, probably because these firms were already relatively conservative prior to SOX. The coefficient on $\mathrm{R} * \mathrm{DR}$ measures this level of conservatism in the pre-SOX period. Its value is $0.030(0.15)$ which is smaller than the corresponding figure for the non-tech sample. Thus it can be concluded that technology firms are not very asymmetrically conservative and the enactment of SOX did not have a significant effect on this tendency.

Although the outcomes for the conservatism hypothesis point to the right direction, the statistical power is low. To obtain more powerful outcomes the sample period is shortened in an attempt to better isolate the effect of the SOX Act. Panel B of table 6 reports the results for the same model applied over the period 2000-2003. While the primary coefficients still point to the expected direction, the t-statistics have improved for five of the six coefficients. The coefficients for the merged sample are significant for both the decrease in the timeliness of good news and the increase in conditional conservatism. This provides evidence for an increase in both conservatism and conditional conservatism shortly after SOX. However the evidence on the separate samples is mixed. Whereas technology firms only experience a decrease in the timeliness of good news, non-technology firms only see an increase in the degree of conditional conservatism. Thus the aggregation of data for both types of firms again comes with a loss of information content.

The findings in Panel A and B of table 2 together would indicate that the increase in conservatism is not really sustainable because the statistical power decreases substantially with the increase of the sample length. An additional regression over the period 2000-2005 (not displayed here) only partially confirms this thought. The findings for the non-technology sample indeed are insignificant; however the findings for the technology sample are significant as are those for the merged sample. This trend could be explained by the occurrence of the dot-com bubble and the disproportionate influence this had on firms in the technology sample. For this regression the pre-SOX period is composed of the fiscal year 2000 and 2001 that are likely to be highly influenced by the dot-com bubble, especially for technology based firms. Thus the increase in conservatism for those firms is probably highly associated with the collapse of the dot-com bubble and less with the enactment of the SOX Act.

Lastly, the degree of conservatism is compared between technology and non-technology firms. This is done by using the same model as above but now the dummy variable CERTI is replaced for the dummy variable TECH. This TECH variable is equal to 1 for firms which belong to the sample of technology firms. Based on the theory the expectation is that technology firms are more conservative (Kwon et al, 2006). However the findings in panel A of table 6 already reveal that this theory does not hold for our sample period. The findings in table 7 confirm this notion. There is no statistical evidence for any difference in conservatism between technology and non-technology firms. Moreover the coefficients indicate that technology firms are slightly less conservative than non-technology firms. Again these findings could be seriously influenced by the effects of the dot-com bubble. Therefore the regression is redone for the period 2002-2005 in panel B of table 6. The outcomes are still insignificant and they indicate a higher degree of conservatism for non-technology firm.

In summary, the findings regarding the conservatism hypothesis are only partially as expected. Our findings indicate that there is an increase in conservatism shortly after the enactment of SOX for the entire sample. However this increase seems to be unsustainable in later years. Furthermore our analyses reveal that the aggregation of data comes with a loss in the information content since technology firms behave differently from non-technology firms when it comes to the application of conservatism. This difference is, though, not in the expected direction. Technology firms seem to be, ceteris paribus, less conservative than non-technology firms although this difference is not significant. 


\subsection{Value Relevance}

Table 8 reports the main results for this hypothesis. For reasons of convenience the 2002 observations which are pre-SOX, which amount 4 and 2 for the NASDAQ and S\&P samples respectively, are assigned to the 2001 sample year. This gives a better picture of the results than dividing the 2002 year in a pre- and post-SOX subsample and it is not influencing the results. Table 8 shows there is indeed a sharp increase in the explanatory power for the regression model after the enactment of SOX. For the technology sample this increase occurs largely immediately after the enactment of SOX, increases further the year thereafter and stays constant afterwards. It seems that firms in the non-technology sector incorporate the increase in value relevance not directly in the first year of SOX but they rather do this a year later. The findings for the merged sample are again in between those of the separate samples.

Figure 1 provides a graphical representation of the findings. The figure further acknowledges there is a clear trend in value relevance over the sample period. The sample period begins with a decline in value relevance and this decline is recovered partially in the years 2001 and 2002. Thus part of the SOX effect is already incorporated in the fiscal year 2001 or this increase is caused by other factors. Anyway there is a clear increase in value relevance after SOX without any other major event related to accounting quality being present at that time.

In order to examine whether the increase in value relevance is statistically significant t-tests are conducted (see table 9). The outcomes show unambiguously that the value relevance for all the sample compositions is higher in the post-SOX period compared to the pre-SOX. All differences are statistically significant at conventional levels and this also holds if unequal variances are assumed. Taking into account that these tests are based on a low number of observations it can be concluded that these results provide very strong evidence for an increase in value relevance after SOX.

The last test examines whether there is, ceteris paribus, a difference in value relevance between technology and non-technology firms (see Table 10). As figure 1 does suppose there is a statistical significant difference in value relevance between the two samples in the pre-SOX period but not in the post-SOX period. The comparison over the entire 1998-2005 period also results in insignificant outcomes. The findings in the pre-SOX period are inevitably influenced by the dot-com bubble and this effect was mostly experienced by technology firms. Therefore, for the comparison of value relevance between technology and non-technology more value is assigned to the post-SOX observations. The results in this period reveal that there is no difference in value relevance between the two types of firms.

Overall, the findings with respect to the value relevance hypothesis do confirm the expectation that value relevance has increased after SOX. The trend in the explanatory power over the sample period indicates strongly that there is an increase in value relevance over this period. This trend is further confirmed by t-tests which indicate that the increase in value relevance in the post-SOX period is highly significant. A comparison of value relevance between technology and non-technology firms reveals that these types of firm do not differ from each other on this accounting quality metric if the dot-com bubble period is left out of consideration.

\section{Discussion - Conclusions}

In general, our results provide evidence that the enactment of SOX has had a positive effect on accounting quality. This is especially evident regarding the earnings management and value relevance measures. In accordance with the study by Cohen et al. (2005) a significant decrease in the use of discretionary accruals after the enactment of SOX was found. Furthermore, the value relevance of accounting information has also increased significantly after SOX has been enacted.

The findings regarding the conservatism hypothesis are nevertheless less convincing. In contrast to Lobo and Zhou (2006) a significant increase in the relevant conservatism measures for the separate samples was not found. The only significant observations are reported for the complete sample over the period 2000-2003. This period coincides with the sample period of Lobo and Zhou (2006) who also use an aggregated sample. Our observations are in fact similar to those of Lobo and Zhou (2006), however if the sample period is prolonged and subsequently decomposed the significance of the findings disappears. One possible explanation for this occurrence could be the explained trade-off which could exist between relevance and reliability. Although the concepts are not mutually exclusive this contrast could explain why the clear increase in value relevance is not accompanied by an increase in conservatism.

Since the results with respect to the conservatism hypothesis where neither significant nor consistent this accounting quality measure also fails the sustainability test. Nevertheless for the other measures there is convincing evidence to conclude that the increase in accounting quality has been sustainable. This outcome can help in the process of finding a justification for the high costs associated with initial SOX compliance. Because these costs are disproportionally born in the first year of compliance it is now possible to spread out these costs over multiple 
pos-SOX years because it has been proved that the positive effects have been persistent. This will result to lower average costs of SOX which can take away some of the critique associated with the high compliance costs.

Another remarkable finding is that technology firms behave differently on various aspect of accounting quality compared to non-technology firms, which implies that the aggregation of data leads to a loss of information content. If for instance a sample of only S\&P-100 firms was used without the exclusion of firms also listed in the NASDAQ-100 composition then the findings would have been different and probably more in the direction of the aggregate sample. Thereby interesting information could have stayed undetected.

Our examination has also revealed that technology firms employ a far greater degree of discretionary accruals implying that they manage earnings to a higher extent. This is not surprising since technology based firms engage in far more complex transactions and activities than non-technology firms, resulting to more complex accounting entries. Examples are the capitalization of development activities and licensing agreements. Experimental research has found evidence for the assertion that managers are more likely to manage earnings when the chance of detection and correction by auditors is smaller (Nelson et al., 2002). This situation is more present at technology firms because of the higher complexity. This can be an explanation for the higher degree of earnings management found at technology firms.

The explanation provided above can also potentially explain why the findings of this research are contrary to those of Kwon et al. (2006) in relation to the conservatism hypothesis. Since technology firms are more difficult to audit they could manage earnings to a higher degree. In contrast to value relevance and conservatism, earnings management and conservatism are more complementary to each other from an accounting quality perspective, namely a lower degree of earnings management can be associated with a higher degree of conservatism. This occurs because earnings management is primarily used to meet targets or benchmarks, which implies that most earnings management is in a positive direction. However, conservatism implies just the contrary, namely that earnings should incorporate positive news more prudently than negative news. For this reason it is not surprising to find that technology firms, managing earnings to a much higher degree, seem to be less conservative in their earnings reporting.

Our analysis also indicates that in the post-SOX period there is almost no difference in value relevance between the two samples. This could be evidence of an undervaluation of technology firms in the post-SOX sample period. The explanation for this is that, ceteris paribus, the market value of technology firms are to a bigger extent based on intangible assets (e.g. Aboody and Lev, 1998; Kallapur and Kwan, 2004). The recognition principles for intangibles are nevertheless much stricter than for tangible assets within the U.S GAAP. Thus, it would be logical that there is a smaller association between book values and market values for technology based firms. For the sample period this trend is only visible in the pre-SOX period but not in the post-SOX period. Therefore undervaluation of technology firms in the post-SOX period is a serious possibility which can potentially be explained as an excessive reaction by investors to the dot-com bubble.

The findings of our work can have several implications for future research. Almost all studies use a random sample of firms included in databases like Computstat North America. These databases consist of all types of firms including technology firms and financial institutions. While most research designs take into account the different accounting characteristics of financial institutions by excluding these firms from the sample, less effort is undertaken to control for the different accounting characteristics of technology based firms. The findings of this research have revealed that there are only slight differences in the reaction to the exogenous shock caused by the SOX Act when it comes to accounting quality. However our findings also indicate that there are cross-sectional differences in accounting quality between technology and non-technology firms. This implies that it can be beneficial for future research to control for these differences by conducting additional tests with adjusted sample compositions.

Another interesting outcome of our work is that the complementary accounting quality measures can conflict with each other. Previous studies have often assumed that all accounting quality measures are complementary to each other (e.g. Barth et al., 2008; Lang et al., 2003). However, a critical evaluation of the underlying principles reveals that the conservatism and value relevance measures are not fully in line with each other. For future research on accounting quality this means that a careful analysis must be made between the scores on these different quality measures. Whether one of these measures must be preferred over the other depends partially on the perspective chosen. The advantages of higher conservatism, as formulated by Watts (2003), accrue primarily to the stakeholders of the company, while higher value relevance is potentially more beneficial for shareholders alone. Thus, more weight should be assigned to these respective metrics based on the preference from a stakeholders or shareholders perspective. 
Finally, our findings can be useful in the process of developing a decent regulatory reaction to the current crisis the financial world is suffering. Despite the great deal of critique on the SOX Act this paper provides empirical evidence for an increase in accounting quality which has also proved to be persistent. Unfortunately, these improvements have not been enough to prevent the current crisis. However, the partial success of previous financial market legislations could strengthen the lawmakers in their attempt to develop a reaction to the current crisis.

\section{Study Limitations}

The chosen research design is of course not free from limitations. The first major problem is that the sample period coincides with a period of heavy economic turmoil. Thus, exogenous factors have possibly an influence on the research results. However, the research design already partially controls for this effect. First of all, the subdivision of the sample in technology and non-technology firms creates the opportunity to investigate how firms which are less vulnerable to the dot-com bubble react to the SOX Act. The findings show that both samples react in the same way to the enactment of SOX. This provides evidence for the assertion that the effects which occur after the enactment of SOX are indeed, partially, contributable to the SOX Act. Furthermore, extra tests are conducted with a shorter pre-SOX period in an attempt to exclude the effects of the dot-com bubble. The results of these tests do not differ from the tests with longer pre-SOX periods.

Another problem with the investigation of the effects of the SOX Act is the enactment data of July 30, 2002 and the fact that U.S. firms are allowed to have a broken book year. This results in pre- and post-SOX samples which are not entirely even in the number of observations. The consequences of this are nevertheless minor; only a very small number of firm reports are before July and the total sample length is deemed as sufficient to neutralize the potential effects the slightly skewed division could have.

With the examination of accounting quality the use of proxies is unavoidable. Implicit to the use of proxies is that they are not free from ambiguity and this creates the next limitation because our conclusions are only based on these proxies. So the use of erroneous proxies could also lead to incorrect conclusions. This problem is partially solved by using multiple measures of accounting quality. Besides, the measures used in our work are already extensively applied in other studies on accounting quality. This increases our confidence in these models as proxies for accounting quality.

The distinction between technology firms and firms which do not belong to this category can not be made entirely objectively. This is inherent to the fact that there is no uniform definition of what is exactly a technology firm. Taking the NASDAQ-100 index as the sample for technology firms is nevertheless an adequate way to distinguish between the types of firms because the listing requirements of the NASDAQ are fairly strict. Together with the fact that the respective samples are of sufficient length this should result in two samples which differ substantially from each other. Our findings do confirm this thought.

\section{References}

Aboody, D. and B. Lev. (1998). The value relevance of intangibles: the case of software capitalization. Journal of Accounting Research 36: 161-191. Doi: 10.2307/2491312, http://dx.doi.org/10.2307/2491312

Aggelopoulos, E., A. Bellas and G. Zafeiropoulos. (2008). Interest rate risk and bank common stock returns: evidence from the Greek banking sector. Investment Research and Analysis Journal 3(1): 32-39.

Ball, R., S.P. Kothari and A. Robin. (2000). The effect of international institutional factors on properties of accounting earnings. Journal of Accounting and Economics 29: 1-51. Doi:10.1016/S0165-4101(00)00012-4, http://dx.doi.org/10.1016/S0165-4101(00)00012-4

Ball, R. (2009). Market and political/regulatory perspectives on the recent accounting scandals. Journal of Accounting Research 47: 277-323. http://dx.doi.org/10.1111/j.1475-679X.2009.00325.x

Barth, M.E., W.R. Landsman and M.H. Lang. (2008). International accounting standards and accounting quality. Journal of Accounting Research 46: 467-498. doi:10.1111/j.1475-679X.2008.00287.x, http://dx.doi.org/10.1111/j.1475-679X.2008.00287.x

Basu, S. (1997). The conservatism principle and the asymmetric timeliness of earnings. Journal of Accounting \& Economics 24: 3-37. Doi:10.1016/S0165-4101(97)00014-1, http://dx.doi.org/10.1016/S0165-4101(97)00014-1

Beaver, W.H., R Lambert and D. Morse. (1980). The information content of security prices. Journal of Accounting and Economics 2: 3-28. Doi:10.1016/0165-4101(80)90013-0, http://dx.doi.org/10.1016/0165-4101(80)90013-0

Black, B., B. Cheffins and M. Klausner. (2006). Liability risk for outside directors: a cross-border analysis. European Financial Management 11: 153-171. Doi:10.1111/j.1354-7798.2005.00280.x, http://dx.doi.org/10.1111/j.1354-7798.2005.00280.x 
Coates, J.C. (2007). The goals and promise of the Sarbanes-Oxley Act. Journal of Economic Perspectives 21: 91-116. Doi:10.1257/jep.21.1.91, http://dx.doi.org/10.1257/jep.21.1.91

Cohen, D., A. Dey and T. Lys. (2005). Trends in earnings management and informativeness of earnings announcements in the pre- and post-Sarbanes Oxley periods. Working paper, Northwestern University.

Dechow, P.M., R.G. Sloan and A.P. Sweeney. 1995. Detecting Earnings Management. The Accounting Review 70: 193-225.

Diamond, D.W. and R. Rajan. (2009). The credit crisis: conjectures about causes and remedies. American Economic Review. NBER Working Paper 14739.

Engel, E., R.M. Hayes and X. Wang. (2007). The Sarbanes-Oxley Act and firms? going -private decisions. Journal of Accounting and Economics 44: 116-145. Doi:10.1016/j.jacceco.2006.07.002, http://dx.doi.org/10.1016/j.jacceco.2006.07.002

Francis, J. and K. Schipper. (1999). Have Financial Statements Lost Their Relevance? Journal of Accounting Research 37: 319-352. Doi:10.2307/2491412, http://dx.doi.org/10.2307/2491412

Goldfarb, B., D. Kirsch and D.A. Miller. (2006). Was there to little entry during the Dot Com Era. Robert H. Smith School of Business.

Goncharov, I., J.R. Werner and J. Zimmerman. (2006). Does compliance with the German Corporate Governance Code have an impact on stock valuation? An empirical analysis. Corporate Governance: An International Review 14: 432-445. Doi:10.1111/j.1467-8683.2006.00516.x, http://dx.doi.org/10.1111/j.1467-8683.2006.00516.x

Healy, P.M. and J.M. Wahlen. (1999). A review of the earnings management literature and its implications for standard setting. Accounting Horizons 13: 365-383. Doi:10.2308/acch.1999.13.4.365, http://dx.doi.org/10.2308/acch.1999.13.4.365

Kallapur, S. and S.Y.S. Kwan. (2004). The value relevance and reliability of brand assets recognized by U.K. firms. The Accounting Review 79: 151-172. Doi:10.2308/accr.2004.79.1.151, http://dx.doi.org/10.2308/accr.2004.79.1.151

Kinney, W.R., Z. Palmrose and S. Scholz. (2004). Auditor independence, non-audit services and restatements: Was the U.S. Government right? Journal of Accounting Research 42: 561-588. Doi:10.1111/j.1475-679X.2004.t01-1-00141.x, http://dx.doi.org/10.1111/j.1475-679X.2004.t01-1-00141.x

Kothari, S.P., A.J. Leone and C.E. Wasley. (2005). Performance matched discretionary accrual measures. Journal of Accounting and Economics 39: 163-197. Doi:10.1016/j.jacceco.2004.11.002, http://dx.doi.org/10.1016/j.jacceco.2004.11.002

Kwon S.S., Q.J. Yin and J. Han. (2006). The effect of differential accounting conservatism on the ?over-valuation? of high-tech firms relative to low-tech firms. Review of Quantitative Finance and Accounting 27: 143-173. http://dx.doi.org/10.1007/s11156-006-8794-3

Lang, M., J.S. Ready and M.H. Yetman. (2003). How representative are firms cross -listed in the United States? An analysis of accounting quality. Journal of Accounting Research 41: 363-386. Doi:10.1111/1475-679X.00108, http://dx.doi.org/10.1111/1475-679X.00108

Leuz, C., D. Nanda and P.D. Wysocki. (2003). Earnings management and investor protection: an international comparison. Journal of Financial Economics 69: 505-527. http://dx.doi.org/10.1016/S0304-405X(03)00121-1

Li, H., M. Pincus and S. Oldhoft Rego. (2008). Market Reaction to Events Surrounding the Sarbanes-Oxley Act of 2002 and Earnings Management. Journal of Law and Economics 51: 111-134. Doi:10.1086/588597, http://dx.doi.org/10.1086/588597

Lim, M. M-H. (2008). Old wine in a new bottle: subprime mortgage crisis ? causes and consequences. The Levy Economic Institute. Working Paper 532.

Lobo, G.J. and J. Zhou. (2006). Did Conservatism in Financial Reporting Increase after the Sarbanes-Oxley Act? Initial Evidence. Accounting Horizons 20: 57-73. Doi:10.2308/acch.2006.20.1.57, http://dx.doi.org/10.2308/acch.2006.20.1.57

McNihols, M.F. (2000). Research design issues in earnings management studies. Journal of Accounting and Public Policy 19: 313-345. Doi:10.1016/S0278-4254(00)00018-1, http://dx.doi.org/10.1016/S0278-4254(00)00018-1

Nelson M.W., J.A. Elliott and R.L. Tarpley. (2002). Evidence from auditors about managers? and auditors? earnings management decisions. The Accounting Review 77: 175-202. Doi:10.2308/accr.2002.77.s-1.175, http://dx.doi.org/10.2308/accr.2002.77.s-1.175 
Ohlson, J.A. (1995). Earnings, book values and dividends in equity valuation. Contemporary Accounting Research 11: 661-687. Doi:10.1111/j.1911-3846.1995.tb00461.x, http://dx.doi.org/10.1111/j.1911-3846.1995.tb00461.x

Penman, S.H. and X-J. Zhang. (2002). Accounting conservatism, the quality of earnings and stock returns. The Accounting Review 77: 237-264. Doi:10.2308/accr.2002.77.2.237, http://dx.doi.org/10.2308/accr.2002.77.2.237

Ribstein, L.E. (2005). Sarbanes-Oxley after three years. University of Illinois Law \& Economics Research.

Ryan, S.G. (2006). Identifying conditional conservatism. European Accounting Review 15: 511-525. Doi:10.1080/09638180601102099, http://dx.doi.org/10.1080/09638180601102099

U.S. House of Representatives. (2002). The Sarbanes-Oxley Act of 2002. Public Law 107-204. Washington D.C.: Government Printing Office.

Watts, R.S. (2003). Conservatism in Accounting Part I: Explanations and Implications. Accounting Horizons 17: 207-221. doi:10.2308/acch.2003.17.3.207, http://dx.doi.org/10.2308/acch.2003.17.3.207

Zhang, I.X. (2007). Economic consequences of the Sarbanes-Oxley Act of 2002. Journal of Accounting and Economics 44: 74-115. doi: 10.1016/j.jacceco.2007.02.002, http://dx.doi.org/10.1016/j.jacceco.2007.02.002

Table 1. Number of firms included in the different samples

\begin{tabular}{|c|c|c|c|}
\hline \multirow[b]{2}{*}{ Accounting Quality Measure } & \multicolumn{3}{|c|}{ Sample } \\
\hline & NASDAQ & $\mathrm{S} \& \mathrm{P}$ & Complete \\
\hline Earnings Management & 75 & 66 & 141 \\
\hline Conservatism & 61 & 69 & 130 \\
\hline Value Relevance & 72 & 73 & 145 \\
\hline
\end{tabular}

Table 2. Descriptive statistics of discretionary accruals in pre- and post-SOX periods for different sample compositions.

\begin{tabular}{lllccc}
\hline Sample & Period & N & Mean & Std. Deviation & Std. Error Mean \\
\hline Complete & pre-SOX & 563 & 0,1412 & 0,4763 & 0,0201 \\
& post-SOX & 549 & 0,0557 & 0,0720 & 0,0031 \\
NASDAQ & pre-SOX & 299 & 0,1834 & 0,3372 & 0,0195 \\
& post-SOX & 291 & 0,0788 & 0,0865 & 0,0051 \\
S\&P & pre-SOX & 266 & 0,0536 & 0,0765 & 0,0047 \\
& post-SOX & 262 & 0,0295 & 0,0327 & 0,0020 \\
\hline
\end{tabular}

The sample period ranges from 1998 till 2005.

Table 3. Comparison of mean discretionary accruals between pre- and post-SOX periods.

\begin{tabular}{|c|c|c|c|c|c|c|c|c|}
\hline \multirow[b]{2}{*}{$\begin{array}{l}\text { Sample } \\
\text { compostion }\end{array}$} & & \multicolumn{4}{|c|}{$\begin{array}{l}\text { T-test for Equality of Means } \\
\text { (equal variances assumed) }\end{array}$} & \multicolumn{3}{|c|}{$\begin{array}{c}\text { T-test for Equality of Means (unequal } \\
\text { variances assumed) }\end{array}$} \\
\hline & & t-statistic & df & Sig. & (2-tailed) & t-statistic & df & $\begin{array}{c}\text { Sig. } \\
\text { (2-tailed) }\end{array}$ \\
\hline \multicolumn{9}{|c|}{ Panel A: Sample period $1998-2005$} \\
\hline Complete & pre-SOX-SOX & 4,1590 & 1110 & & $0,00 *$ & 4,2093 & 588 & $0,00 *$ \\
\hline NASDAQ & pre-SOX-SOX & 5,1301 & 588 & & $0,00 *$ & 5,1916 & 338 & $0,00^{*}$ \\
\hline $\mathrm{S} \& \mathrm{P}$ & pre-SOX-SOX & 4,6886 & 526 & & $0,00 *$ & 4,7132 & 360 & $0,00^{*}$ \\
\hline \multicolumn{9}{|c|}{ Panel B: Sample period 2001-2003 } \\
\hline Complete & pre-SOX-SOX & 3,2306 & 415 & & $0,00 *$ & 2,9032 & 221 & $0,00^{*}$ \\
\hline NASDAQ & pre-SOX-SOX & 1,0499 & 220 & & 0,30 & 1,0305 & 152 & 0,30 \\
\hline S\&P & pre-SOX-SOX & 5,1666 & 196 & & $0,00 *$ & 3,9634 & 74 & $0,00^{*}$ \\
\hline
\end{tabular}

* Indicates significance at the $\mathrm{p}<0,01$ level.

Table 4. Comparison of mean discretionary accruals in the post-SOX period over different lengths.

\begin{tabular}{llccc}
\hline & & \multicolumn{3}{c}{ T-test for Equality of Means (equal variances assumed) } \\
\hline Sample & & t-statistic & df & Sig. (2-tailed) \\
\hline Complete & $(2002-2003)-(2002-2005)$ & 0,0457 & 818 & 0,96 \\
NASDAQ & $(2002-2003)-(2002-2005)$ & $-0,0827$ & 432 & 0,93 \\
S\&P & $(2002-2003)-(2002-2005)$ & $-0,4873$ & 390 & 0,63 \\
\hline
\end{tabular}


Table 5. Comparison of mean discretionary accruals between technology and non-technology firms.

\begin{tabular}{lcccc}
\hline & & \multicolumn{3}{c}{ T-test for Equality of Means (unequal variances assumed) } \\
\hline Period & & t-statistic & df & Sig. (2-tailed) \\
\hline Entire sample period & NASDAQ - S\&P & 8,3985 & 663 & $0,00^{*}$ \\
Pre-SOX & NASDAQ - S\&P & 6,4719 & 332 & $0,00^{*}$ \\
Post-SOX & NASDAQ - S\&P & 9,0297 & 379 & $0,00^{*}$ \\
\hline
\end{tabular}

* Indicates significance at the $\mathrm{p}<0,01$ level.

Table 6. Regression comparing conservatism between the pre- and post-SOX periods.

\begin{tabular}{|c|c|c|c|c|c|c|c|}
\hline \multirow[b]{3}{*}{ Variable } & \multirow[b]{3}{*}{ Predicted Sign } & \multirow{2}{*}{\multicolumn{3}{|c|}{ Panel A: 1998-2005 }} & \multirow{2}{*}{\multicolumn{3}{|c|}{ Panel B: 2000-2003 }} \\
\hline & & & & & & & \\
\hline & & NASDAQ & S\&P & Complete Sample & NASDAQ & $\mathrm{S} \& \mathrm{P}$ & Complete Sample \\
\hline \multirow[t]{2}{*}{ Intercept } & $?$ & 0,025 & 0,047 & 0,038 & 0,013 & 0,055 & 0,033 \\
\hline & & $(0,00 *)$ & $\left(0,00^{*}\right)$ & $(0,00 *)$ & $\left(0,06^{* * *}\right)$ & $(0,00 *)$ & $(0,00 *)$ \\
\hline \multirow[t]{2}{*}{ DR } & $?$ & $-0,010$ & $-0,005$ & $-0,006$ & $-0,005$ & $-0,011$ & $-0,004$ \\
\hline & & $(0,34)$ & $(0,45)$ & $(0,31)$ & $(0,71)$ & $(0,25)$ & $(0,59)$ \\
\hline \multirow[t]{2}{*}{$\mathrm{R}$} & + & 0,004 & 0,006 & 0,001 & 0,043 & $-0,00$ & 0,033 \\
\hline & & $(0,37)$ & $(0,46)$ & $(0,84)$ & $(0,00 *)$ & $(0,99)$ & $(0,00 *)$ \\
\hline \multirow[t]{2}{*}{$\mathrm{R} * \mathrm{DR}$} & + & 0,030 & 0,034 & 0,043 & $-0,016$ & 0,052 & 0,014 \\
\hline & & $(0,15)$ & $(0,03 * *)$ & $\left(0,00^{*}\right)$ & $(0,49)$ & $(0,04 * *)$ & $(0,40)$ \\
\hline \multirow[t]{2}{*}{ CERTI } & $?$ & 0,005 & 0,017 & 0,012 & 0,016 & 0,007 & 0,015 \\
\hline & & $(0,47)$ & $\left(0,00^{*}\right)$ & $(0,00 *)$ & $(0,09 * * *)$ & $(0,38)$ & $(0,02 * *)$ \\
\hline \multirow[t]{2}{*}{ CERTI*DR } & $?$ & 0,009 & $-0,002$ & 0,002 & $-0,003$ & 0,005 & $-0,002$ \\
\hline & & $(0,50)$ & $(0,82)$ & $(0,83)$ & $(0,87)$ & $(0,71)$ & $(0,87)$ \\
\hline \multirow[t]{2}{*}{ CERTI*R } & - & $-0,003$ & $-0,006$ & $-0,005$ & $-0,039$ & $-0,005$ & $-0,036$ \\
\hline & & $(0,74)$ & $(0,64)$ & $(0,41)$ & $(0,00 *)$ & $(0,77)$ & $(0,00 *)$ \\
\hline \multirow[t]{2}{*}{ CERTI*R*DR } & + & 0,013 & 0,068 & 0,039 & $(0,050)$ & 0,084 & 0,076 \\
\hline & & $(0,72)$ & $(0,01 *)$ & $\left(0,08^{* * *}\right)$ & $(0,21)$ & $(0,03 * *)$ & $(0,01 * *)$ \\
\hline Adjusted $\mathrm{R}^{2}$ & & $3,80 \%$ & $17,91 \%$ & $8,40 \%$ & $17,22 \%$ & $19,50 \%$ & $16,91 \%$ \\
\hline $\mathrm{N}$ & & 567 & 583 & 1135 & 284 & 292 & 568 \\
\hline
\end{tabular}

$*, * *, * * *$ Indicate significance at $\mathrm{p}<0,01, \mathrm{p}<0,05$ and $\mathrm{p}<0,10$, respectively.

Table 7. Comparison of conservatism between technology and non-technology firms.

\begin{tabular}{|c|c|c|c|}
\hline \multicolumn{4}{|c|}{$\begin{array}{l}\text { Model: } X_{i l} / P_{i t-1}=\alpha_{0}+\alpha_{1} D R_{i t}+\beta_{0} R_{i t}+\beta_{1} R_{i t} * D R_{i t}+\gamma_{0} T E C H_{i t}+ \\
\gamma_{1} T E C H_{i t} * D R_{i t}+\gamma_{2} T E C H_{i t} * R_{i t}+\gamma_{3} T E C H_{i t} * R_{i t} * D R_{i t}+v_{i t}\end{array}$} \\
\hline Variable & Predicted Sign & Panel A: 1998-2005 & Panel B: 2002-2005 \\
\hline Intercept & $?$ & $\begin{array}{l}0,057 \\
\left(0,00^{*}\right)\end{array}$ & $\begin{array}{l}0,064 \\
\left(0,00^{*}\right)\end{array}$ \\
\hline DR & $?$ & $\begin{array}{l}-0,008 \\
(0,16)\end{array}$ & $\begin{array}{l}-0,007 \\
(0,33)\end{array}$ \\
\hline $\mathrm{R}$ & + & $\begin{array}{l}0,001 \\
(0,88)\end{array}$ & $\begin{array}{l}0,000 \\
(0,97)\end{array}$ \\
\hline $\mathrm{R} * \mathrm{DR}$ & + & $\begin{array}{l}0,061 \\
\left(0,00^{*}\right)\end{array}$ & $\begin{array}{l}0,103 \\
\left(0,00^{*}\right)\end{array}$ \\
\hline $\mathrm{TECH}$ & $?$ & $\begin{array}{l}-0,028 \\
\left(0,00^{*}\right)\end{array}$ & $\begin{array}{l}-0.033 \\
\left(0,00^{*}\right)\end{array}$ \\
\hline TECH*DR & $?$ & $\begin{array}{l}0,004 \\
(0,60)\end{array}$ & $\begin{array}{l}0,007 \\
(0,51)\end{array}$ \\
\hline $\mathrm{TECH} * \mathrm{R}$ & - & $\begin{array}{l}0,002 \\
(0,86)\end{array}$ & $\begin{array}{l}0,001 \\
(0,94)\end{array}$ \\
\hline $\mathrm{TECH} * \mathrm{R} * \mathrm{DR}$ & + & $\begin{array}{l}-0,020 \\
(0,34)\end{array}$ & $\begin{array}{l}-0,054 \\
(0,10)\end{array}$ \\
\hline Adjusted $\mathrm{R}^{2}$ & & $13,90 \%$ & $18,42 \%$ \\
\hline $\mathrm{N}$ & & 1150 & 576 \\
\hline
\end{tabular}

$*, * *, * * *$ Indicate significance at $\mathrm{p}<0,01, \mathrm{p}<0,05$ and $\mathrm{p}<0,10$, respectively. 
Table 8. Explanatory power of book values on market values regression for different samples.

\begin{tabular}{lccc}
\hline Model: $P_{i t}=\alpha_{o}+\alpha_{1} B V E_{i t}+\alpha_{2}$ EARN $_{i t}+v_{i t}$ & Adjusted R & \\
\cline { 2 - 4 } Year & NASDAQ & S\&P & Complete \\
\hline 1998 & 0,186 & 0,324 & 0,324 \\
1999 & 0,044 & 0,276 & 0,152 \\
2000 & 0,059 & 0,295 & 0,174 \\
2001 & 0,250 & 0,352 & 0,328 \\
\hline 2002 & 0,398 & 0,359 & 0,411 \\
2003 & 0,446 & 0,495 & 0,436 \\
2004 & 0,453 & 0,564 & 0,513 \\
2005 & 0,435 & 0,492 & 0,453 \\
& & & 130 \\
Average N & 61 & 69 & 139 \\
\hline
\end{tabular}

Table 9. Comparison of value relevance (adjusted $\mathrm{R}^{2}$ ) between the pre- and post-SOX periods.

\begin{tabular}{|c|c|c|c|c|c|c|c|}
\hline \multirow[b]{2}{*}{ Sample } & & \multicolumn{3}{|c|}{$\begin{array}{l}\text { T-test for Equality of Means } \\
\text { (equal variances assumed) }\end{array}$} & \multicolumn{3}{|c|}{$\begin{array}{l}\text { T-test for Equality of Means } \\
\text { (unequal variances assumed) }\end{array}$} \\
\hline & & $\mathrm{t}$ & df & $\begin{array}{c}\text { Sig. } \\
\text { (2-tailed) }\end{array}$ & $\mathrm{t}$ & $\mathrm{df}$ & $\begin{array}{c}\text { Sig. } \\
\text { (2-tailed) }\end{array}$ \\
\hline Total & pre-SOX-SOX & $-4,0068$ & 6 & $0,00^{*}$ & $-4,0068$ & 4 & $0,02 * *$ \\
\hline NASDAQ & pre-SOX-SOX & $-5,8081$ & 6 & $0,00^{*}$ & $-5,8081$ & 3 & $0,01 * *$ \\
\hline $\mathrm{S} \& \mathrm{P}$ & pre-SOX-SOX & $-3,5979$ & 6 & $0,01 * *$ & $-3,5979$ & 4 & $0,02 * *$ \\
\hline
\end{tabular}

$*, * *, * *$ Indicate significance at $\mathrm{p}<0,01, \mathrm{p}<0,05$ and $\mathrm{p}<0,10$, respectively.

Table 10. Comparison of value relevance (adjusted $\mathrm{R}^{2}$ ) between technology and non-technology firms.

\begin{tabular}{llllll} 
& & \multicolumn{2}{l}{ T-test for Equality of Means } & (unequal variances assumed) \\
\hline Period & & $\mathrm{t}$ & $\mathrm{df}$ & $\mathrm{Sig}$ & \\
\hline Entire sample period & NASDAQ - S\&P & $-1,5408$ & 12 & 0,15 & \\
Pre-SOX & NASDAQ - S\&P & $-3,3720$ & 4 & $0,03 * *$ \\
Post-SOX & NASDAQ - S\&P & $-0,9965$ & 3 & 0,39 & \\
\hline
\end{tabular}

$*, * *, * *$ Indicate significance at $\mathrm{p}<0,01, \mathrm{p}<0,05$ and $\mathrm{p}<0,10$, respectively.

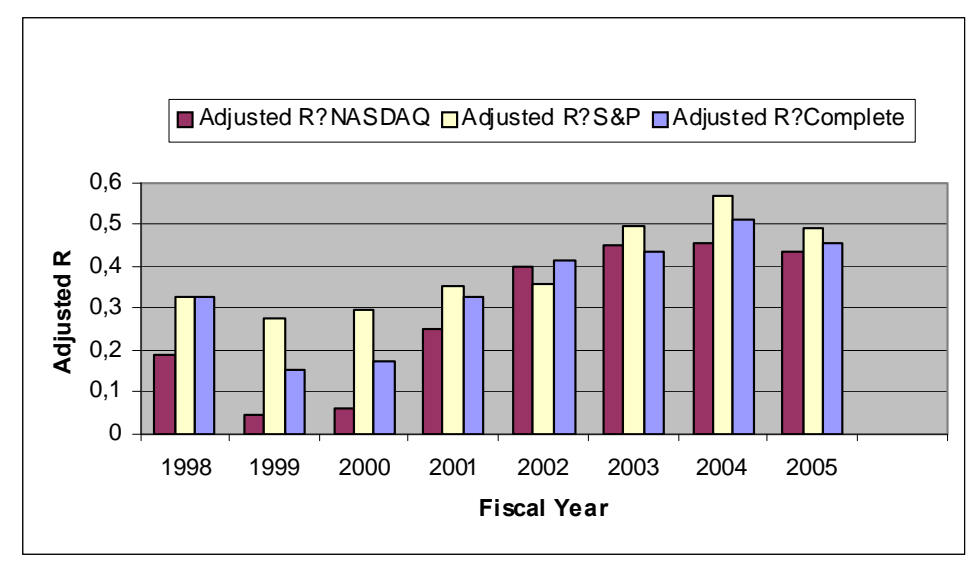

Figure 1. Explanatory power of book values on market values regression for different samples. 